\title{
Development of a new rain attenuation model for tropical location
}

\author{
Joseph Mom, Silas Soo Tyokighir, Gabriel Igwue \\ Department of Electrical and Electronics Engineering, Faculty of Engineering, Joseph Sarwuan Tarka University, \\ Makurdi, Nigeria
}

\begin{tabular}{l} 
Article Info \\
\hline Article history: \\
Received Jul 9, 2021 \\
Revised Sep 9, 2021 \\
Accepted Sep 16, 2021 \\
\hline
\end{tabular}

\section{Keywords:}

Fade mitigation

Ku-band

NIGCOMSAT-1R

Proposed model

Rain attenuation

\begin{abstract}
This study proposes a new rain attenuation prediction model (RAM) based on the rain cell concept for tropical locations. The new model addresses the research gap in the international telecommunications union (ITU) model. Results obtained show that the proposed RAM predicted the possibility of signal across seven (7) out of thirteen (13) stations monitored. The predicted attenuation values were $18.3427 \mathrm{~dB}, 18.8106 \mathrm{~dB}, 18.3921 \mathrm{~dB}, 13.8062 \mathrm{~dB}, 20.8803 \mathrm{~dB}, 9.4519 \mathrm{~dB}$, and $19.6018 \mathrm{~dB}$ for Jalingo, Jos, Makurdi, Mubi, Otukpo, Sokoto, and Abuja respectively. However, the RAM predicted outage across six stations with predicted attenuation values of $31.7040 \mathrm{~dB}, 26.8302 \mathrm{~dB}, 28.6635 \mathrm{~dB}, 29.6562$ $\mathrm{dB}, 28.8827 \mathrm{~dB}$, and $30.0614 \mathrm{~dB}$ for Akwa-Ibom, Benin, Donga, Port-Harcourt, Owerri, and Aba respectively. The proposed RAM hence suggests an additional Ku-band spot beam power of at least 331.97 watts for Nigeria's Nigerian communication satellite-1 (NIGCOMSAT-1R) Ku-band transponder to overcome the predicted attenuation across the six stations which recorded signal outage. The results from this study can be used by network engineers for the implementation of fade mitigation techniques (FMTs) such as site diversity and power control to aid telecommunication networks anticipate changes and allocate resources accordingly.
\end{abstract}

This is an open access article under the $\mathrm{CC}$ BY-SA license.

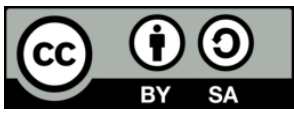

\section{Corresponding Author:}

Silas Soo Tyokighir

Department of Electrical and Electronics Engineering, Faculty of Engineering

Joseph Sarwuan Tarka University

P.M.B 2373, Makurdi, Benue State, Nigeria

Email: tyokighir.soo@uam.edu.ng

\section{INTRODUCTION}

Attenuation due to rain increases significantly especially for frequencies exceeding $10 \mathrm{GHz}$. Tropical locations such as Nigeria are characterized by high rainfall rates and large raindrop sizes. Successful studies on the impact of rain on earth-space communication links have been carried out over the years. To determine the appropriate fade margins and diversity factors for earth-space communication links, studies on the performance and prediction of attenuation due to rain on earth-space links become necessary. Research campaigns by [1]-[5] over tropical and temperate climate by [6] amongst others provide experimental results for attenuation prediction due to rainfall. As such, more studies are needed in tropical locations such as Nigeria since attenuation prediction due to rain is location-specific.

The international telecommunications union recommendation (ITU-R) recommends a global rainattenuation prediction model for satellite links but it lacks physical meaning because it is an empirical model while the estimation of the effective path length is dependent on both frequency and elevation angle [1]. The rain attenuation predicted by the ITU-R model varies non-monotonically with percentage of time and rain 
rate in low latitudes (between $36^{\circ} \mathrm{S}$ and $36^{\circ} \mathrm{N}$ ) and low elevation angles below $25^{\circ}$ [2]. To this end, a new rain attenuation prediction method is proposed based on the effective number of rain cells. The performance of the proposed model is compared with the ITU-R model [7], the Bryant model [4], the Svajatogor model [8], and the Garcia model [9]. The proposed model is hybrid and takes advantage from both the empirical and physical methods to provide better prediction accuracy when compared with on-site measurements and other existing models. Finally, the anomalous behaviors from other models are improved in the proposed model.

\section{RELATED WORK}

According to [10], a rain cell is a volume in which convective events occur. There have been some proposed models based on the rain cell concept and physical approaches. The cylindrical cell model [11], [12] was proposed under the assumption that rainfall in the rain cell is uniform. Another prominent model based on weather radar measurements is the EXCELL model [13], [14]. For the horizontal cross-section of the rain cell, the EXCELL model included monoaxial and biaxial models. A better version of the model was recently proposed, and it was based on rain type discrimination. The SC EXCELL model, sometimes known as the modified EXCELL model [14], is a popular name for it. A new model [15] was developed that included both an exponential and a Gaussian component in the rain cell. The exponential component describes the stratiform-like low rain rate outside the cell, while the Gaussian component describes the convective-like high rain rate core. The goal of this study's experimental attempt is to collect data on signal levels and rain rate during signal propagation sessions on satellite-to-earth links. The availability of rain attenuation data improves the precision of rain attenuation estimates and provides a foundation for the development of household rain attenuation models [16]-[20].

The rain attenuation experimental setup includes equipment that monitors both the precipitates and the satellite signal at the same time. The Nigerian environmental and climate observatory programme (NECOP) station, the tropical rainfall measurement mission data (TRMM), the Nigerian meteorological agency (NiMet), and rain gauge experiments are all used to measure precipitation. Empirical and physical methodologies are used in general investigations on rain attenuation. The physical method seeks to replicate the actual physical behavior of the attenuation process from the satellite to the earth station, whereas the empirical method is based on measurements from databases from various climatic zones and stations. Although the empirical method is advocated in [21]-[23], when applied to terrestrial radio communications operating in equatorial and tropical climates, the empirical prediction method produces unsatisfactory results. The prediction model proposed by [24]-[26] has confirmed this claim. In [17], [18] have created some more rain attenuation prediction models for terrestrial and earth-space linkages. These models, on the other hand, are primarily tailored for equatorial and temperate climates [27]-[29]. This research proposes a new rain attenuation prediction model that may be used to estimate wireless radio signal coverage in rainy environments, particularly in tropical areas.

\section{RESEARCH METHOD}

In this section, the experimental setup for signal downlink from Nigeria's Nigerian communication satellite-1 (NIGCOMSAT-1R) Ku-band transponder is explained. The approach, proposed model, and instrumentation are also discussed in this section.

\subsection{Experimental setup for beacon experiment}

Two different experimental setups are used to calculate the measured attenuation owing to rain. All atmospheric conditions for composite links were taken into account to allow for link margin and uplink power adjustments to compensate for the beacon satellite receiving antenna's losses [30]-[33]. For this work, the NIGCOMSAT-1R satellite specifications are being used, with an orbital position of $42.5{ }^{\circ} \mathrm{E}$ and a downlink frequency of $12.519 \mathrm{GHz}$ for $\mathrm{Ku}$-band with horizontal polarization. Two units of separate satellite receiving antennae were co-located in the same rain cell for the experiment. Two beacon receiving terminals in receive-only mode in the digital video broadcasting (DVB-S2) network running in a time division multiple access (TDMA) scheme with additional receiving antennas made up the independent units. The beacon receiving terminals are set up to only receive satellite downlink data, with one monitoring the signal level in clear skies and the other determining the signal level in wet conditions. This is required to determine attenuation due to rain by subtracting the signal level acquired under clear skies from the value obtained under rainy skies, as stated in (1). The technique should be repeated for various rain events, with the appropriate attenuation values noted.

$$
\text { Attenuation }(\mathrm{dB})=\mathrm{RSL}_{\text {clear sky }}-\mathrm{RSL}_{\text {rainy }}
$$


where $\mathrm{RSL}_{\text {clear sky }}$ is the received signal level in the clear sky while $\mathrm{RSL}_{\text {rainy }}$ is the received signal level in rain.

\subsection{Approach}

The beacon signal is received with horizontal receiving polarization on a $90 \mathrm{~cm}$ offset parabolic dish at an elevation angle of 42.5 degrees. The NIGCOMSAT-1R satellite's down-converted Ku-band signal is then transmitted to a digital satellite meter and a signal monitoring device for signal level measurement and logging into a computer unit. The geometric specifications for the receiving antenna are as shown in Figure 1, with an antenna diameter of $0.9 \mathrm{~m}$, a height of $3 \mathrm{~m}$, an antenna gain of $37 \mathrm{~dB}$, and an effective isotropic radiated power (EIRP) of 48 to $55 \mathrm{dBw}$ for a $12.519 \mathrm{GHz}$ link.

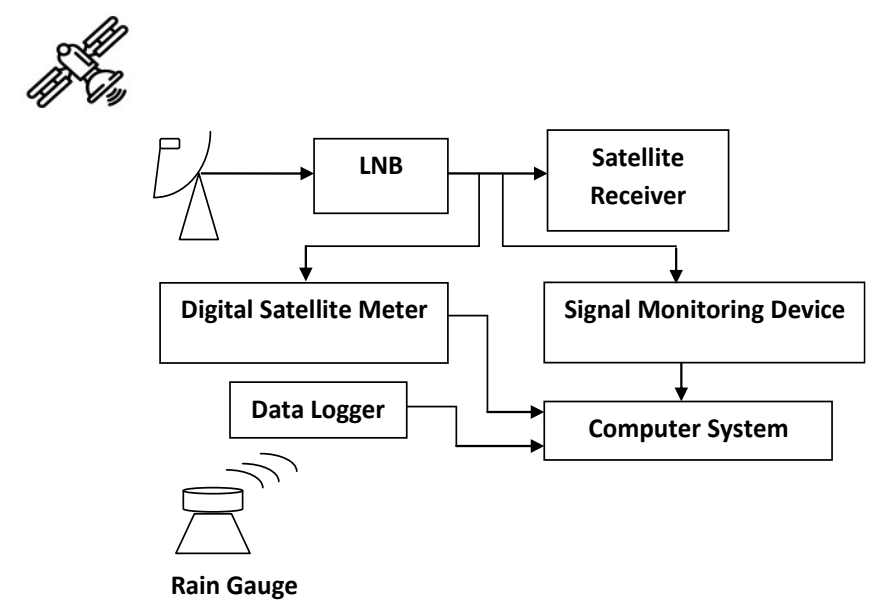

Figure 1. Beacon experiment setup in a tropical location

\subsection{Instrumentation}

Equipment used to carry out the experiment includes a rain gauge for measuring rainfall rates at different percentages of time, reflector antenna having specific gain, compass, coaxial cable port connector, connecting cable, radiofrequency power meter for measuring power levels, satellite signal tracking device, and timer.

\subsection{Proposed model}

Daily rainfall rates are obtained and validated using data from the tropical rainfall measurement mission (TRMM) and rain gauge experiments, as well as data from the Nigerian meteorological agency (NiMet) [7]. Recommends using the model presented by [34] to convert rainfall rates to one-minute integration time. There are two types of rain: stratiform $(\mathrm{R}<12 \mathrm{~mm} / \mathrm{h})$ and convective $(\mathrm{R}>12 \mathrm{~mm} / \mathrm{h})$. If a portion of the rain rate is stratiform, the distance is calculated by multiplying the entire time taken by that fraction by an advection velocity of $6 \mathrm{~m} / \mathrm{s}$ for each rain event. Otherwise, a $10 \mathrm{~m} / \mathrm{s}$ advection velocity is used for convective cell regions. This technique is performed for each of the threshold values evaluated, and the distances calculated are saved individually. The rain cell number distribution $\mathrm{n}_{2}$ is predicted by the probability distribution function (PDF) of the distances, whereas the rain cell size distribution $\mathrm{n}_{1}$ is simply predicted by the cumulative distribution function (CDF) [6]. The effective number of rain cells $\left(\mathrm{N}_{\text {eff }}\right)$ is calculated using the constants $n_{1}$ and $n_{2}$. The proposed approach is divided into five steps, as stated in (2)-(9), which are being as:

1) Step one: calculate the effective number of rain cells $\left(\mathrm{N}_{\mathrm{eff}}\right)$ given as:

$$
\mathrm{N}_{\mathrm{eff}}=\mathrm{n}_{1}+\mathrm{n}_{2}
$$

where: $\mathrm{n}_{1}$ and $\mathrm{n}_{2}$ is the rain cell number and rain cell size distribution respectively.

2) Step two: calculate the effective path length for a single rain cell $\left(\mathrm{L}_{\mathrm{H}}\right)$ as shown in:

$$
\mathrm{L}_{\mathrm{H}}=\frac{\mathrm{H}_{\mathrm{R}}-\mathrm{H}_{\mathrm{S}}}{\tan \theta}[\mathrm{km}]
$$

where: $H_{R}=$ rain height obtained from $(26) H_{s}=$ station height; $\theta=$ elevation angle. 
3) Step three: the effective path length $\left(\mathrm{L}_{\mathrm{eff}}\right)$ is now calculated based on the effective number of rain cells in (2) as:

$$
\mathrm{L}_{\mathrm{eff}}=\frac{\mathrm{L}_{\mathrm{H}} \mathrm{N}_{\mathrm{eff}}}{\cos \theta}[\mathrm{km}]
$$

where: $\mathrm{L}_{\mathrm{H}}=$ effective path length from (3); $\mathrm{N}_{\text {eff }}=$ effective number of rain cells; $\theta=$ elevation angle.

4) Step four: Calculate the attenuation due to rain as:

$$
A_{0.01}=\gamma R_{0.01} L_{e f f} d B
$$

where: $L_{\text {eff }}$ is the effective path length given from (4) and $\gamma R_{0.01}$ is the specific attenuation for $99.99 \%$ availability obtained from the procedure described in [7] given as:

$$
\gamma \mathrm{R}_{0.01}=\mathrm{kR}_{0.01 \%}^{\alpha}
$$

where: $\mathrm{k}$ and $\propto$ are regression constants obtained from [7] and depend on antenna polarization. $\mathrm{R}_{0.01}$ is the rainfall rate for $0.01 \%$ of time obtained from [34] as shown in:

$$
\mathrm{R}_{0.01}(\mathrm{~mm} / \mathrm{h})=\alpha \mathrm{M}^{\beta}
$$

where: $M$ denotes the mean annual accumulation of rain for a given location; $\alpha$ and $\beta=12.2903$ and 0.2973 respectively.

5) Step five: calculate attenuation for other percentages of time $p$ as shown in:

$$
A_{p}(d B)=A_{0.01}\left(\frac{p}{0.01}\right)^{-\left[0.655+0.033 \ln (p)-0.045 \ln \left(A_{0.01}\right)-z \sin \theta(1-p)\right]}
$$

where $p$ is the percentage probability of interest and $\mathrm{z}$ is given as:

$$
\begin{aligned}
& \mathrm{z}=0 \text { if } \mathrm{p} \geq 1 \% \\
& \text { if } \mathrm{p}<1 \%, z=0 \text { for } \varphi \geq 36^{\circ} \\
& \mathrm{z}=-0.005(|\varphi|-36) \text { for } \theta \geq 25^{\circ} \text { and }|\varphi|<36^{\circ} \\
& \mathrm{z}=-0.005(|\varphi|-36)+1.8-4.25 \sin \theta \text { for } \theta<25^{\circ} \text { and }|\varphi|<36^{\circ}
\end{aligned}
$$

$\varphi$ and $\theta$ are the latitude of the earth station and elevation angle respectively.

\subsection{Bryant attenuation model}

Derived a model which consisted variables such as the height of rain and the effective rain cell [4]. The model is given by (11)-(19) as shown in:

$$
\begin{aligned}
& \mathrm{D}=340\left(\mathrm{R}_{\mathrm{p}}^{-1.2}\right)[\mathrm{km}] \\
& \mathrm{D}_{\mathrm{m}}=\left(\frac{2}{\pi}\right)^{\mathrm{D}}
\end{aligned}
$$

where $R_{p}$ is the rain rate. The slant path length $(\mathrm{L})$ can then be calculated as:

$$
\mathrm{L}=\frac{\mathrm{H}_{\mathrm{R}}}{\tan \theta}
$$

where: $H_{R}$ is the rain height and $\theta$ is the elevation angle. Estimation of the rain height is done as shown in:

$$
\mathrm{H}_{\mathrm{R}}(\mathrm{km})=4.5+0.0005 \mathrm{R}_{\mathrm{p}}^{1.65}
$$

where: $\mathrm{R}_{\mathrm{p}}$ is the rain rate for the given location. The slant path can then be calculated as shown in: 
and

$$
\mathrm{L}_{\mathrm{s}}=\frac{\mathrm{H}_{\mathrm{R}}-\mathrm{H}_{\mathrm{s}}}{\sin \theta} \text { for } \theta \geq 5^{\circ}[\mathrm{km}]
$$

$$
\mathrm{L}_{\mathrm{S}}=\frac{2\left(\mathrm{H}_{\mathrm{R}}-\mathrm{H}_{\mathrm{HMSL}}\right)}{\left[\sin ^{2} \theta+2\left(\mathrm{H}_{\mathrm{R}}-\mathrm{H}_{\mathrm{HMSL}}\right) / \mathrm{R}_{\mathrm{E}}\right]^{1 / 2}+\sin \theta} \text { for } \theta<5^{\circ}[\mathrm{km}]
$$

where: $H_{R}$ and $\theta$ height of rain and elevation angle respectively while $H_{H M S L}$ is the height above sea level and $\mathrm{R}_{\mathrm{E}}$ is the radius of the earth. Attenuation due to rainfall is hence obtained as:

$$
A_{0.01}=1.57 D_{m} k_{n} \gamma R_{0.01} \frac{L_{S}}{\xi L+D} \text { for } R_{0.01}>3 m m / h
$$

The cross over coefficient denoted $\mathrm{k}_{\mathrm{n}}$ is given as:

$$
\mathrm{k}_{\mathrm{n}}=\exp \left(0.007 \mathrm{R}_{\mathrm{p}}\right)
$$

The cross-over coefficient optimizes the mean diameter of the equivalent single cell over the full rain-rate gauge so that it produces the same attenuation in a given slant path as a set of multiple cells. The Rho factor denoted $\xi$ is given as shown in:

$$
\xi=\left\{\begin{array}{c}
\frac{1}{\sqrt{2}} \exp (\sin \theta) \theta \leq 55^{\circ} \\
1.1 \tan \theta \theta>55^{\circ}
\end{array}\right.
$$

where: $\theta$ denotes the elevation angle.

\subsection{Svjatogor model}

The model developed by [8] is given by (20)-(25) outlined by the following steps:

$$
\mathrm{H}_{\mathrm{R}}(\mathrm{km})=\frac{2.7}{\log _{10}\left(0.3 \mathrm{R}_{\mathrm{p}}+1.5\right)}+0.0015 \mathrm{R}_{\mathrm{p}}
$$

where: $R_{p}$ denotes the rain rate. The reduction factor for specific paths is given as:

$$
\mathrm{K}_{\mathrm{rs}}=\mathrm{e}^{\mathrm{Y}}
$$

where:

$$
Y=-0.0045 R_{p}^{0.68}\left[\frac{H_{R}}{\tan \theta}\right]^{0.6}
$$

With rain attenuation given as:

$$
A(d B)=k R_{p}^{\propto} L_{s} K_{r s}
$$

where: $\mathrm{L}_{\mathrm{s}}$ is the slant path given in (24); $\mathrm{K}_{\mathrm{rs}}$ is the reduction factor given by (21). $\mathrm{k}$ and $\alpha$ are constants obtained from the ITU-R recommendations in [7].

$$
\begin{aligned}
& \mathrm{L}_{\mathrm{S}}(\mathrm{km})=\frac{\mathrm{H}_{\mathrm{R}}-\mathrm{H}_{S}}{\sin \theta} \text { for } \theta \geq 5^{\circ} \\
& \mathrm{L}_{\mathrm{S}}(\mathrm{km})=\frac{2\left(\mathrm{H}_{\mathrm{R}}-\mathrm{H}_{S}\right)}{\left[\sin ^{2} \theta+\frac{2\left(\mathrm{H}_{\mathrm{R}}-\mathrm{H}_{S}\right)}{\mathrm{R}_{\mathrm{e}}}\right]^{\frac{1}{2}}+\sin \theta} \text { for } \theta<5^{\circ}
\end{aligned}
$$

where: $R_{e}$ is the radius of the earth and is taken as $8500 \mathrm{~km} ; H_{s}$ is the station height; $H_{R}$ is the rain height and $\theta$ is the elevation angle.

\subsection{The ITU-R model}

The ITU-R P. 618-9 model [35] is given by (26)-(39) as shown in:

The rain height is denoted $\mathrm{H}_{\mathrm{R}}$ where:

$$
\mathrm{H}_{\mathrm{R}}=\mathrm{h}_{0}+0.36 \mathrm{~km}
$$


$\mathrm{h}_{0}=0^{\circ} \mathrm{C}$ isotherm height

Estimation of slant path length $\mathrm{L}_{\mathrm{S}}$ is given as:

$$
\mathrm{L}_{\mathrm{s}}=\frac{\mathrm{H}_{\mathrm{R}}-\mathrm{H}_{\mathrm{s}}}{\sin \theta}
$$

with $\theta$ and $H_{s}$ are the elevation angle and station height respectively. The horizontal projection $L_{G}$ is given as:

$$
\mathrm{L}_{\mathrm{G}}=\mathrm{LS} \cos \theta
$$

The rainfall rate for $99.99 \%$ availability can be obtained from rain gauge experiments or rainfall databases for the specific location. The rainfall rate can be given by the following relationship as suggested by the ITU-R P.838-3 recommendations. It is given by:

$$
\gamma \mathrm{R}_{0.01}=\mathrm{kR}_{0.01}^{\propto}
$$

The constants $\mathrm{k}$ and $\alpha$ are gotten from recommendation ITU-R P.838-3 [7]. The next step is to calculate the horizontal reduction factor denoted by $\mathrm{r}_{\mathrm{h} 0.01}$ for $99.99 \%$ availability. The horizontal reduction factor is given as:

$$
\mathrm{r}_{\mathrm{h} 0.01}=\frac{1}{1+0.78 \sqrt{\left(\frac{\mathrm{L}_{\mathrm{G}}^{*} \mathrm{R}_{0.01}}{\mathrm{f}}\right)-0.38\left[1-\exp \left(-2 \mathrm{~L}_{\mathrm{G}}\right)\right]}}
$$

where: $\mathrm{f}=$ frequency $(\mathrm{GHz})$

The vertical adjustment factor for $99.99 \%$ availability is realized as:

$$
\mathrm{L}_{\mathrm{R}}=\frac{\mathrm{L}_{\mathrm{G}} \mathrm{r}_{0.01}}{\cos \theta} \text { for } \rho>\theta
$$

otherwise,

$$
\mathrm{L}_{\mathrm{R}}=\frac{\mathrm{H}_{\mathrm{R}}-\mathrm{H}_{\mathrm{S}}}{\sin \theta}, \text { for } \rho \leq \theta
$$

where:

$$
\rho=\tan ^{-1}\left(\frac{\mathrm{H}_{\mathrm{R}}-\mathrm{H}_{\mathrm{S}}}{\mathrm{L}_{\mathrm{G}} \mathrm{r}_{\mathrm{h} 0.01}}\right)
$$

therefore,

$$
\mathrm{V}_{0.01}=\frac{1}{1+\sqrt{\sin \theta\left[31\left(1-\exp \left(-\frac{\theta}{1+\sigma}\right)\right) \frac{\sqrt{\mathrm{L}_{\mathrm{G}} \mathrm{VR}_{0.01}}}{\mathrm{f}^{2}}-0.45\right]}}
$$

where:

$$
\sigma=36-|\varphi|, \text { for }|\varphi|<36^{\circ} \text { or } \sigma=0 \text {, for }|\varphi| \geq 36^{\circ}
$$

with $\varphi$ known to be the latitude of the location the effective path length $\mathrm{L}_{\mathrm{eff}}(\mathrm{km})$ through rain is calculated as:

$$
\mathrm{L}_{\mathrm{E}}=\mathrm{L}_{\mathrm{R}} \mathrm{V}_{0.01}
$$

The final step is to estimate the rain attenuation exceeded for $99.99 \%$ and is given by:

$$
\mathrm{A}_{0.01}=\gamma \mathrm{R}_{0.01} \mathrm{~L}_{\mathrm{E}}
$$

To calculate for other percentages of time the following expression can be used:

$$
A_{p}(d B)=A_{0.01}\left(\frac{P}{0.01}\right)^{-\left[0.655+0.033 \ln (p)-0.045 \ln \left(A_{0.01}\right)-z \sin \theta(1-p)\right]}
$$


where $\mathrm{p}$ is the percentage probability of interest and $\mathrm{z}$ is given by:

$$
\begin{aligned}
& z=0 \text { if } p \geq 1 \% \\
& z=0 \text { for } \varphi \geq 36^{\circ} \text { if } p<1 \% \\
& z=-0.005(|\varphi|-36) \text { for } \theta \geq 25^{\circ} \text { and }|\varphi|<36^{\circ} \\
& z=-0.005(|\varphi|-36)+1.8-4.25 \sin \theta, \text { for } \theta<25^{\circ} \text { and }|\varphi|<36^{\circ}
\end{aligned}
$$

\subsection{Garcia-Lopez attenuation model}

In (40) and (41) shows the procedure proposed by [9] for deriving the attenuation due to rainfall and rain heights respectively. The model is given as shown in (40).

$$
A=\frac{k^{\alpha} L_{s}}{\left[a+\left\{\frac{L_{s}\left(b R+c L_{s}+d\right.}{e}\right\}\right.}
$$

The method derived by [9] for attenuation prediction depends on four coefficients. These coefficients are regarded as worldwide coefficients and are useful for determining the attenuation for different percentages of time for an average year. The coefficients of the model are denoted a, b, c, and d with corresponding values of $0.7,18.35,-16.51$, and 2408 respectively. For locations such as Nigeria, the coefficients for a, b, c, and $\mathrm{d}$ are $0.72,7.6,-4.75$, and 2408 respectively [20]. $\mathrm{k}$ and $\alpha$ are determined as given in [7]. The slant path length is gotten from (27) while the rain height is given as shown in:

$$
\mathrm{H}_{\mathrm{r}}(\mathrm{km})=\left\{\begin{array}{c}
40<\Psi<36^{\circ} \\
4-0.075\left(|\Psi|-36^{\circ}\right) \Psi \geq 36^{\circ}
\end{array}\right.
$$

where: $\Psi=$ latitude of earth station

\section{RESULTS AND DISCUSSION}

\subsection{Rainfall distribution of the study area}

The study area for the beacon experiment is Longitude $8.88{ }^{\circ} \mathrm{E}$ and Latitude $9.91{ }^{\circ} \mathrm{N}$ which is a hypothetical location for NIGCOMSAT-1Rs backup station. The location has two seasons which include the dry and wet seasons. The wet or rainy season usually lasts from late March to October while the dry or nonrainy season spans the months of November to February. The rainfall data used in this study is obtained from rain gauge experiments, the tropical rainfall measurement mission, Nigeria environmental, and climatic observatory (NECOP) propagation mission, and validated with the Nigerian meteorological agency (NIMET). The rain gauge experiment and attenuation estimation on the earth-space link lasted for 17 months. The study area experiences small amounts of rain during the dry season due to the tropical continental air mass over the location while the wet season experiences heavier amounts of rain due to the maritime air mass moisture from the South [36]-[44]. The average yearly precipitation for the study location is $1239.20 \mathrm{~mm}$.

\subsection{Results for rain attenuation prediction}

The estimated rain attenuation obtained for Ku-band at $42.5^{\circ}$ elevation angle for the 13 stations using the different attenuation prediction models is compared. Results show that attenuation values predicted gradually decrease with an increase in percentage exceedance. From Figure 2(a), for a system design of $99.99 \%$ availability, an attenuation of $0.7399 \mathrm{~dB}, 12.2015 \mathrm{~dB}, 21.7352 \mathrm{~dB}, 31.7040 \mathrm{~dB}$, and $29.8778 \mathrm{~dB}$ is predicted by the Svajatogor, Garcia, ITU-R, the proposed model, and the Bryant model respectively. Since the maximum power of Nigeria's NIGCOMSAT-1R Ku band transponder is $150 \mathrm{w}$, both the Bryant and proposed model suggest signal outage for $0.01 \%$ unavailability. For a system design of 36.5 days/yr to 8.77 hrs/yr unavailability, Figures 2(a)-(d), Figure 3(a)-(d), Figure 4(a) and 4(b), Figure 5(a)-(c) show that all five models estimate the possibility of signal across all thirteen (13) stations. This is because of a signal loss due to rain that ranged from $0.008725 \mathrm{~dB}(1.002 \mathrm{w})$ to $8.6743 \mathrm{~dB}(7.369 \mathrm{w})$. From Figure 2(b), the Svajatogor, Garcia, and ITU-R model estimate signal attenuation values of $0.8310 \mathrm{~dB}(1.211 \mathrm{w}), 11.951 \mathrm{~dB}(15.671 \mathrm{w})$, $20.1965 \mathrm{~dB}(104.629 \mathrm{w})$ which suggests the possibility of signal at $99.99 \%$ availability. The proposed model and Bryant model however estimated attenuation values of $26.830 \mathrm{~dB}(481.948 \mathrm{w})$ and $26.365 \mathrm{~dB}(433.052$ w) respectively. Both models suggest that the NIGCOMSAT-1R Ku band transponder would require an additional spot beam power of at least $283.052 \mathrm{w}$ to overcome the predicted attenuation. Results from Figure 2(b) further show the possibility of signal at $90 \%$ to $99.9 \%$ across all models for the thirteen (13) 
selected stations. From Figure 2(c), all five models suggest the availability of signal at $90 \%$ to $99.9 \%$ for the selected station. However, the proposed and Bryant model estimate signal outage for $99.99 \%$ availability due to an attenuation estimation of $28.663 \mathrm{~dB}$ and $27.683 \mathrm{~dB}$ respectively. An attenuation of $0.7955 \mathrm{~dB}, 11.7815$, and $20.78 \mathrm{~dB}$ was predicted by the Svajatogor, Garcia, and ITU-R rain models and suggest the availability of signal at $99.99 \%$ availability.

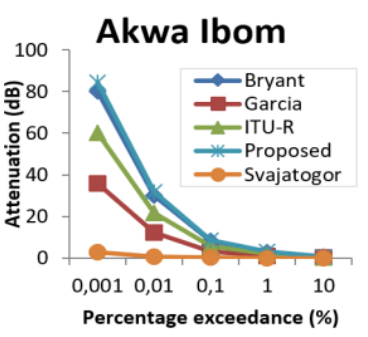

(a)

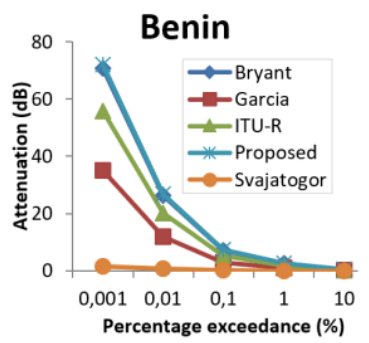

(b)

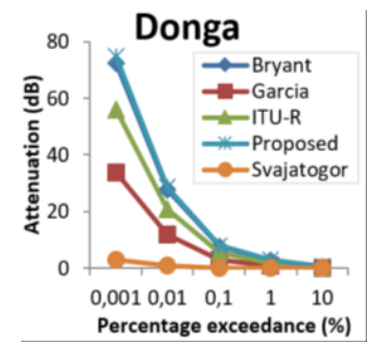

(c)

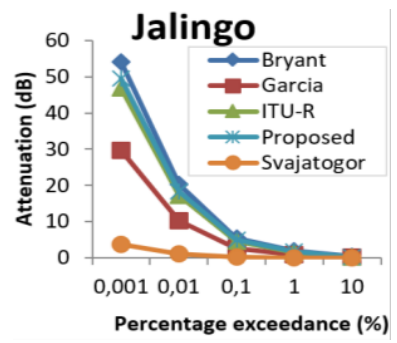

(d)

Figure 2. Performance of rain attenuation models in (a) Akwa Ibom, (b) Benin, (c) Donga and (d) Jalingo

Figure 2(c) hence suggests a power shortage of $585.021 \mathrm{w}$ and $436.538 \mathrm{w}$ estimated by the proposed and Bryant rain attenuation prediction models respectively. For a system design of $99.999 \%$ availability, only the Svajatogor model suggests the possibility of signal at $99.999 \%$ availability. The Garcia, ITU-R, proposed and Bryant model hence estimate additional power requirements of $2207.925 \mathrm{w}, 407,746.52 \mathrm{w}, 17911269.27 \mathrm{w}$, and $30408700.25 \mathrm{w}$ respectively for the possibility of signal of $99.999 \%$ availability. Results from Figure 2(d) show that for a system design of 53 minutes of outage a year $(0.01 \%$ unavailability), attenuation values of $1.0175 \mathrm{~dB}, 10.331 \mathrm{~dB}, 17.2151 \mathrm{~dB}, 20.2657 \mathrm{~dB}$, and 18.3427 were realized for the Svajatogor, Garcia, ITU$\mathrm{R}$ Bryant and proposed models respectively. Based on results, signal would be impossible at $99.999 \%$ availability as suggested by the Garcia, Bryant, ITU-R, and proposed model. For $99.99 \%$ availability, all models suggest the possibility of signal across the selected station. Generally, only the Svajatogor model predicts the possibility of signal at $90 \%$ to $99.999 \%$ availability. From Figures 3(a) and 3(b), and considering for $99.99 \%$ availability, the Bryant model predicted the highest attenuation value of $20.6045 \mathrm{~dB}$ and 20.3016 $\mathrm{dB}$ for Jos and Makurdi respectively while the proposed model predicted attenuation of $18.8106 \mathrm{~dB}$ and $18.3922 \mathrm{~dB}$ for the two stations (Jos and Makurdi). All five models suggest the possibility of signal for a system design of 53 minutes of outage a year for the two stations. At time exceedance of $0.001 \%$, signal is impossible across the two stations (Jos and Makurdi) according to all models except that of Svajatogor.

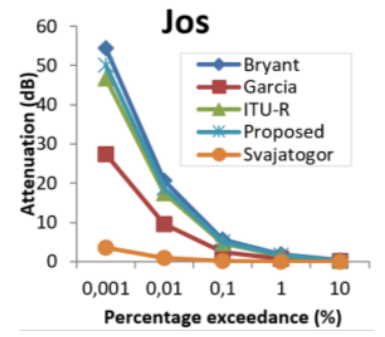

(a)

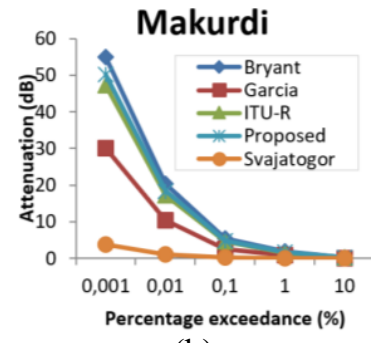

(b)

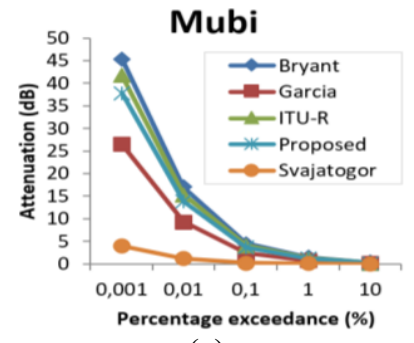

(c)

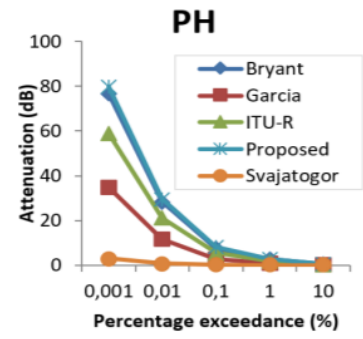

(d)

Figure 3. Performance analysis of rain attenuation models in (a) Jos, (b) Makurdi, (c) Mubi and (d) PH

Due to a power requirement of $128.85 \mathrm{w}(21.100 \mathrm{~dB})$ necessary in overcoming attenuation due to rain for Mubi station as suggested by the ITU-R model, signal can be said to be possible for $99.99 \%$ availability as shown in Figure 3(c). Results on Figures 3(c) and 3(d) further suggest signal unavailability for a system design of 5.26 minutes outage in a year as estimated by the Garcia, ITU-R, proposed and Bryant model. However, Figures 3(c) and 3(d) show that signal is possible at $90 \%$ to $99.99 \%$ as suggested by the ITU-R, Garcia, and Svajatogor models. From Figure 3(d), the Bryant and proposed model estimate additional Ku band spot beam power of $541.512 \mathrm{w}$ and $773.911 \mathrm{w}$ respectively to overcome the attenuation for Port Harcourt earth station. 
From Figure 4(a), only the proposed and Bryant model suggests signal outage for $90 \%$ to $99.99 \%$ of time. All other models suggest the possibility of signal for the time range. From Figure 4(b), only the Bryant model predicts signal outage for a system design of 53 minutes of outage in a year. This is due to a $12.065 \mathrm{w}$ power shortage resulting in scattering of signals due to rain.

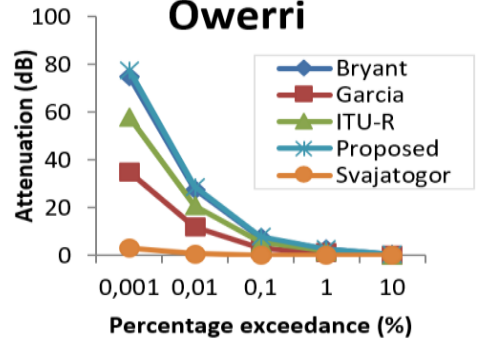

(a)

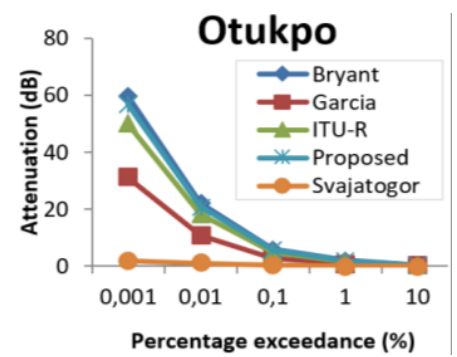

(b)

Figure 4. Performance comparison of rain attenuation prediction models (a) Owerri and (b) Otukpo

Attenuation due to rain predicted by all five models for $90 \%$ to $99.999 \%$ of time ranged from $0.008725 \mathrm{~dB}$ to $36.0593 \mathrm{~dB}$ for the selected station shown in Figure 5(a). However, signal is possible only at $90 \%$ to $99.99 \%$ availability. At $0.001 \%$ of time, Figure 5(a) shows that the proposed model's attenuation prediction value is lower than that of the ITU-R signifying a trend change in attenuation prediction as results from Figures 2(a)-(d), 3(a)-(d), 4(a) and (b) show that the proposed model estimates higher attenuation values than the ITU-R for higher rainfall rates. The predicted attenuation for the proposed model was $26.0567 \mathrm{~dB}$ while that of the ITU-R model was $35.5938 \mathrm{~dB}$. From the results shown in Figure 5(b), attenuation values for $0.01 \%$ unavailability ranged from $0.7695 \mathrm{~dB}$ to $30.0614 \mathrm{~dB}$ across all five models. The attenuation values were $0.7695 \mathrm{~dB}, 11.556 \mathrm{~dB}, 21.23 \mathrm{~dB}, 28.6903 \mathrm{~dB}$, and $30.0614 \mathrm{~dB}$ for the Svajatogor, Garcia, ITU-R, Bryant, and proposed model respectively. The signal loss estimates from Figure $5(\mathrm{~b})$ show that signal is possible based on predictions by the Svajatogor, Garcia, and ITU-R model. The Bryant and proposed model however suggest signal outage for $99.99 \%$ availability. For a system design of $0.001 \%$ unavailability, the proposed model estimated attenuation of $80.4543 \mathrm{~dB}$ suggesting total signal outage and a spot beam power exceeding $111027356.596 \mathrm{w}$ to overcome the signal outage. However, for the link availability range of $90 \%$ to $99.9 \%$ all five models suggest the possibility of signal across the station. Results from Figure 5(c) suggest the possibility of signal for a system design of $99.99 \%$ availability across all models for the selected station. For a design of $0.001 \%$ unavailability, only the Svajatogor model suggests the possibility of signal. The proposed, Bryant, Garcia, and ITU-R models predicted signal outages across the station. The rain attenuation predicted by the proposed model for Abuja station showed agreement with the results from the work of [39] for Abuja as predicted attenuation due to rain was $19.6018 \mathrm{~dB}$ for this study and $18.7135 \mathrm{~dB}$ for [39]. The proposed model estimated attenuation at $99.9 \%$ to $99.999 \%$ for the thirteen cities as shown in Table 1. Sokoto and Aba recorded the lowest and highest attenuation of $9.45 \mathrm{db}$ and $30.06 \mathrm{db}$ for $0.01 \%$ respectively.

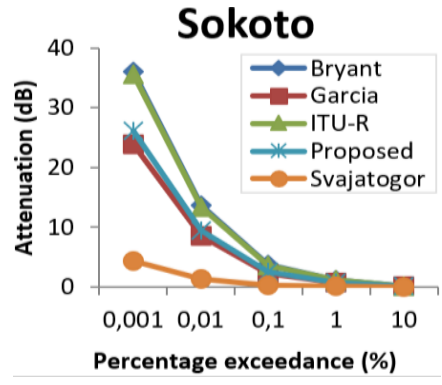

(a)

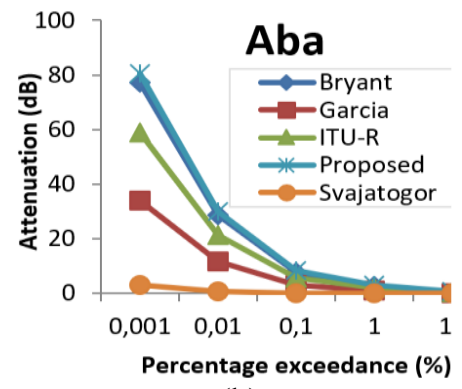

(b)

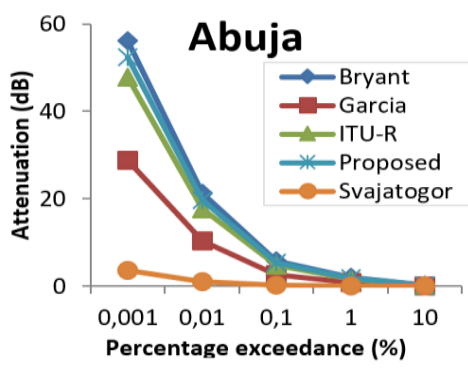

(c)

Figure 5. Performance analysis of rain attenuation prediction models (a) Sokoto, (b) Aba, and (c) Abuja 
Table 1. Rain attenuation and geometric characteristics of receiver sites

\begin{tabular}{llllllll}
\hline No. & City & $0.1 \%$ & $0.01 \%$ & $0.001 \%$ & \multicolumn{1}{c}{ Lat/Long } & $\mathrm{H}_{\mathrm{s}}$ & $\mathrm{R}_{0.01}$ \\
\hline 1 & Aba & 8.198 & 30.061 & 80.454 & $5.12^{\circ} \mathrm{N} / 7.37^{\circ} \mathrm{E}$ & 205 & 123.26 \\
2 & Abuja & 5.323 & 19.602 & 52.453 & $9.07^{\circ} \mathrm{N} / 7.39^{\circ} \mathrm{E}$ & 360 & 105.65 \\
3 & Akwaibom & 8.674 & 31.704 & 84.597 & $4.90^{\circ} \mathrm{N} / 7.85^{\circ} \mathrm{E}$ & 43 & 125.75 \\
4 & Benin & 7.297 & 26.830 & 71.928 & $6.33^{\circ} \mathrm{N} / 5.60^{\circ} \mathrm{E}$ & 88 & 118.19 \\
5 & Donga & 7.990 & 28.663 & 74.830 & $7.75^{\circ} \mathrm{N} / 10.17^{\circ} \mathrm{E}$ & 344 & 121.10 \\
6 & Jalingo & 4.936 & 18.343 & 49.536 & $8.89^{\circ} \mathrm{N} / 11.37^{\circ} \mathrm{E}$ & 351 & 103.26 \\
7 & Jos & 5.128 & 18.811 & 50.090 & $9.89^{\circ} \mathrm{N} / 8.85^{\circ} \mathrm{E}$ & 1220 & 104.16 \\
8 & Makurdi & 4.897 & 18.392 & 50.262 & $7.73{ }^{\circ} \mathrm{N} / 8.53^{\circ} \mathrm{E}$ & 91 & 103.35 \\
9 & Mubi & 3.652 & 13.806 & 37.874 & $10.26^{\circ} \mathrm{N} / 13.26^{\circ} \mathrm{E}$ & 572 & 93.92 \\
10 & Otukpo & 5.601 & 20.880 & 56.679 & $7.19^{\circ} \mathrm{N} / 8.13^{\circ} \mathrm{E}$ & 170 & 108.01 \\
11 & Owerri & 7.867 & 28.882 & 77.372 & $5.48^{\circ} \mathrm{N} / 7.01^{\circ} \mathrm{E}$ & 75 & 121.44 \\
12 & PH & 8.049 & 29.656 & 79.773 & $4.81^{\circ} \mathrm{N} / 7.04{ }^{\circ} \mathrm{E}$ & 12 & 122.64 \\
13 & Sokoto & 2.480 & 9.451 & 26.056 & $13.00^{\circ} \mathrm{N} / 5.24^{\circ} \mathrm{E}$ & 265 & 83.48 \\
\hline
\end{tabular}

\section{CONCLUSION}

This study proposed a new rain attenuation prediction model based on the rain cell concept. The constants used in developing the proposed model were obtained from Ku-band beacon experiments in tropical locations. The proposed model was compared with four other rain attenuation prediction models. The results obtained have shown that the ITU-R P.618 model, Bryant model, Svajatogor model, Garcia model, and the proposed model can be used to predict attenuation due to rain at $\mathrm{Ku}$-band in different selected locations in Nigeria. From the values of attenuation predicted by the proposed model for $99.99 \%$ availability, signal is seen to be possible across seven stations. The predicted attenuation values were $18.3427 \mathrm{~dB}, 18.8106 \mathrm{~dB}, 18.3921$ $\mathrm{dB}, 13.8062 \mathrm{~dB}, 20.8803 \mathrm{~dB}, 9.4519 \mathrm{~dB}$, and 19.6018 dB for Jalingo, Jos, Makurdi, Mubi, Otukpo, Sokoto, and Abuja respectively. However, signal fade-out is predicted across the remaining six stations with predicted attenuation values of $31.7040 \mathrm{~dB}, 26.8302 \mathrm{~dB}, 28.6635 \mathrm{~dB}, 29.6562 \mathrm{~dB}, 28.8827 \mathrm{~dB}$, and $30.0614 \mathrm{~dB}$ for Akwa Ibom, Benin, Donga, Port-Harcourt, Owerri, and Aba respectively. The proposed model hence suggests an additional $\mathrm{Ku}$-band spot beam power of at least $331.97 \mathrm{w}$ to overcome the predicted attenuation across the six stations which recorded signal outage. Since higher frequencies are more prone to attenuation, further studies and models for rain attenuation prediction on Ka-band are required.

\section{ACKNOWLEDGMENTS}

The authors would like to thank the Nigerian weather monitoring stations such as NiMet and NECOP for making hydrometeor data available for this study.

\section{REFERENCES}

[1] W. Kang, T. Kim, S. Park, I. Lee, and J. Pack, "Modeling of Effective Path-Length Based on Rain Cell Statistics for Total Attenuation Prediction in Satellite Link," in IEEE Communications Letters, vol. 22, no. 12, pp. 2483-2486, December 2018, doi: 10.1109/LCOMM.2018.2873007.

[2] C. Lu et al., "A New Rain Attenuation Prediction Model for the Earth-Space Links," in IEEE Transactions on Antennas and Propagation, vol. 66, no. 10, pp. 5432-5442, October 2018, doi: 10.1109/TAP.2018.2854181.

[3] M. O. Odedina and T. J. Afullo, "Determination of rain attenuation from electromagnetic scattering by spherical raindrops: Theory and experiment," in Radio Science, vol. 45, no. 01, pp. 1-15, February 2010, doi: 10.1029/2009RS004192.

[4] G. H. Bryant, I. A. Riva, and G, Brussard, "Rain attenuation statistics from rain column, diameters and heights," International Journal of Satellite Communications, vol. 19, no. 3, pp. 263-283, May 1999, doi: 10.1002/sat.673.

[5] W. L. Stutzman and K. M. Yon, "A simple rain attenuation model for earth-space radio links operating at 10-35 GHz," in Radio Science, vol. 21, no. 1, pp. 65-72, January-February 1986, doi: 10.1029/RS021i001p00065.

[6] P. O. Akuon and T. J. O. Afullo, "Path reduction factor modeling for terrestrial links based on rain cell growth," IEEE Africon '11, 2011, pp. 1-6, doi: 10.1109/AFRCON.2011.6072006.

[7] ITU-R, "Specific Attenuation Model for Rain for Use in Prediction Methods," Recommendation P.838-3, ITU-R P Series. Int. Telecomm, Union, pp. 1-17, 2005.

[8] L. Svjatogor, "A new rain attenuation prediction model in Russian Prostranstvennaia korelacia vypadenjija dozdjej vdol zemnoj poverchnostji," Theme 5 of the Established Telecommunication Working Group, pp. 1-12, June 1985.

[9] J. A. Garcia-Lopez, J. M. Hernando, and J. M. Selga, "Simple rain attenuation prediction method for satellite radio links," in IEEE Transactions on Antennas and Propagation, vol. 36, no. 3, pp. 444-448, March 1988, doi: 10.1109/8.192129.

[10] R. K. Crane, "A global model for rain attenuation prediction," EASCON'78; Electronics and Aerospace Systems Convention, March 1978, pp. 391-395.

[11] P. Misme and P. Waldteufei, "A model for precipitation on a microwave earth-space link," Radio Science, no. 15, pp. 655-665, May-June 1980, doi: 10.1029/RS015i003p00655. 
[12] C. Riva, "Spatial characteristics of propagation parameters: A review. International Workshop on Propagation Impairment Mitigation for Millimeter Wave," Radio Systems, pp. 1-6, July 2002.

[13] C. Capsoni, L. Luini, A. Paraboni, C. Riva, and A. Martellucci, "A New Prediction Model of Rain Attenuation That Separately Accounts for Stratiform and Convective Rain," in IEEE Transactions on Antennas and Propagation, vol. 57, no. 1, pp. 196-204, January 2009, doi: 10.1109/TAP.2008.2009698.

[14] L. Luini and C. Capsoni, "MultiEXCELL: A New Rain Field Model for Propagation Applications," in IEEE Transactions on Antennas and Propagation, vol. 59, no. 11, pp. 4286-4300, November 2011, doi: 10.1109/TAP.2011.2164175.

[15] F. Laurent," HYCELL-A new hybrid model of the rain horizontal distribution for propagation studies: Modeling of the rain cell," Radio Science, vol. 38, no. 3, pp. 1-4, June 2003, doi: 10.1029/2002rs002803.

[16] R. W. Middlestead, "Digital communications with emphasis on data modems," John Wiley \& Sons, pp. 1-18, 2017.

[17] L. Luini and C. Capsoni, "A Rain Cell Model for the Simulation and Performance Evaluation of Site Diversity Schemes," in IEEE Antennas and Wireless Propagation Letters, vol. 12, pp. 1327-1330, 2013, doi: 10.1109/LAWP.2013.2285400.

[18] J. M. Mom, S. Tyokighir, and G. Igwue, "Modification of the ITU-R P.530-17 Rain Attenuation Prediction Model", International Journal of Engineering Research and Technology, vol. 10, no. 9, pp. 119-125, September, 2021.

[19] J. Ojo and P. Owolawi, "Development of one-minute rain-rate and rain-attenuation contour maps forsatellite propagation system planning in a subtropical country: South Africa," Advances in Space Research, vol. 54, no. 8, pp. 1487-1501, October 2014, doi: 10.1016/j.asr.2014.06.028

[20] P. Panchal and J. Rutvij, "Performance analysis and simulation of rain attenuation models at $12-40 \mathrm{GHz}$ band for an earth space path over Indian cities," Procedia Computer Science, no. 79, 2016, pp. 801-808, doi: 10.1016/j.procs.2016.03.110.

[21] ITU-R, "Characteristics of precipitation for propagation modelling," Recommendation P.837-4 ITU-R P Series, pp. 1-9, 2017.

[22] R. K. Crane, "A local model for the prediction of rain-rate statistics for rain-attenuation models," in IEEE Transactions on Antennas and Propagation, vol. 51, no. 9, pp. 2260-2273, September 2003, doi: 10.1109/TAP.2003.816299.

[23] V. Ramachandran and V. Kumar, "Invariance of Accumulation Time Factor of Ku-Band Signals in the Tropics," Journal of Electromagnetic Waves and Applications, vol. 19, no. 11, pp. 1501-1509, April 2005, doi: $10.1163 / 156939305775701868$.

[24] J. S. Mandeep, "Rain attenuation statistics over a terrestrial link at $32.6 \mathrm{GHz}$ at Malaysia," IET Microwave Antennas Propagation, vol. 3, no.7, pp. 1086-1093, November 2009, doi: 10.1049/iet-map.2008.0186.

[25] J. S. Mandeep, "Slant path rain attenuation comparison of prediction models for satellite applications in Malaysia," Journal of Geophysical research: Atmospheres, vol. 114, no. 17, pp. 1-5, September 2009, doi: 10.1029/2009JD011852.

[26] J. S. Mandeep, "Analysis of rain attenuation prediction models at Ku-band in Thailand," Advances in space research, vol. 49, no. 3, pp. 566-571, February 2012, doi: 10.1016/j.asr.2011.11.005.

[27] T. V. Omotosho and C. O. Oluwafemi, "Impairment of radio wave signal by rainfall on fixed satellite service on earth-space path at 37 stations in Nigeria," Journal of Atmospheric and Solar-Terrestrial Physics, vol. 71, no. 8-9, pp. 830-840, June 2009, doi: 10.1016/j.jastp.2009.03.016.

[28] M. Samad, F. Diba, and D. Choi, "A survey of rain fade models for earth-space telecommunication links-Taxonomy, methods and comparative study," Remote sensing, vol. 13, no. 10, pp. 1-9, May 2021, doi: 10.3390/rs13101965.

[29] S. Shrestha and D. Choi, "Study of rain attenuation in Ka band for satellite communication in South Korea," Journal of atmospheric and Solar-terrestrial Physics, vol. 148, pp. 53-63, October 2016, doi: 10.1016/j.jastp.2016.08.008.

[30] A. I. O. Yussuff and N. H. K. Khamis, "Determination of melting layer boundaries and attenuation evaluation in Equatorial Malaysia at Ku-band," Bulleting of electrical engineering and informatics, vol. 3, no. 4, pp. 293-302, December 2014, doi: 10.11591/eei.v3i4.308.

[31] A. I. Yussuff, N. H. Bin H. Khamis, and A. Yahya, "Performance evaluation of rain attenuation models in a tropical station," International Journal of Electrical and Computer Engineering (IJECE), vol. 4, no. 5, pp. 782-789, October 2014, doi: 10.11591/ijece.v4i5.6583.

[32] A. I. Yussuff, G. Tavwo, and N. H. H. Khamis, "Rain attenuation models at ka band for selected stations in the southwestern region of Nigeria," Indonesian Journal of Electrical Engineering and Informatics (IJEEI), vol. 7 , no. 1, pp. 130-137, March 2019, doi: 10.11591/ijeei.v7i1.621.

[33] L. J. Ippolito, "Propagation Effects Modeling and Prediction," in Satellite Communications Systems Engineering: Atmospheric Effects, Satellite Link Design and System Performance, Wiley, 2017, pp. 138-204, doi: 10.1002/9781119259411.ch7.

[34] J. Chebil and T. Rahman, "Development of $1 \mathrm{~min}$ rain rate contour maps for microwave applications in Malaysia Peninsula," Electronic Letters, vol. 35, no. 12, pp. 1712-1774, June 1999, doi: 10.1049/el:19991188.

[35] ITU-R, "Propagation Data and Prediction Methods Required for the Design of Earth-Space Telecommunication Systems," Recommendation ITU-R, 2015.

[36] S. Begum and I. E. Otung, "Rain cell size distribution inferred from rain gauge and radar data in the UK," Radio science, vol. 44, no. 2, pp. 1-7, April 2009, doi: 10.1029/2008RS003984.

[37] D. Y. Choi, J. Y. Pyun, S. K. Noh, and S. W. Lee, "Comparison of measured rain attenuation in the $12.25 \mathrm{GHz}$ band with predictions by the ITU-R model," International journal of antennas and propagation, pp. 1-5, September 2011, doi: $10.1155 / 2012 / 415398$.

[38] T. S. Ibiyemi, M. O. Ajewole, J. S. Ojo, and O. O. Obiyemi, "Rain rate and rain attenuation prediction with experimental rain attenuation efforts in south-western Nigeria," 2012 20th Telecommunications Forum (TELFOR), 2012, pp. 327-329, doi: 10.1109/TELFOR.2012.6419213.

[39] K. Igwe, O. Oyedum, O. Ajewole, and A. Aibinu, "Evaluation of some rain attenuation prediction models for satellite communication at $\mathrm{Ku}$ and Ka bands," Journal of Atmospheric and Solar-Terrestrial Physics, vol. 188, pp. 53-61, March 2019, doi: 10.1016/j.jastp.2019.03.005. 
[40] A. Idrissa, B. Jafri, Y. Lam, and A. Manhal, "Rain attenuation in broadband satellite service and worst month analysis," Indonesian Journal of Electrical Engineering and Computer Science, vol. 15, no. 3, pp. 1443-1451, September 2019, doi: 10.11591/ijeecs.v15.i3.pp1443-1451.

[41] N. Ya'acob, N. Tajudin, M. R. Alui, N. F. Naim, M. Kassim, and W. N. W. Muhamad, "Development of software for Ku-band signal availability due to rain attenuation," Indonesian Journal of Electrical Engineering and Computer Science, vol. 13, no. 3, pp. 1252-1258, March 2019, doi: 10.11591/ijeecs.v13.i3.pp1252-1258.

[42] A. O. Bang and P. L. Ramteke, "Mobile Computing Application Design and Development Issues," International Journal of Science and Research, vol. 2, no. 2, pp. 560-563, February 2013.

[43] Md. A. Samad, Md. R. Ahmed, and S. Z. Rashid, "An overview of rain attenuation research in Bangladesh," Indonesian Journal of Electrical Engineering and Computer Science, vol. 23, no. 2, pp. 902-909, August 2021, doi: 10.11591/ijeecs.v23.i2.pp902-909.

[44] P. H. Linga, H. U. Iddi, and M. Kissaka, "Rain attenuation distribution for satellite microwave links application in Tanzania," Indonesian Journal of Electrical Engineering and Computer Science, vol. 17, no. 2, pp. 982-987, February 2020, doi: 10.11591/ijeecs.v17.i2.pp982-987.

\section{BIOGRAPHIES OF AUTHORS}

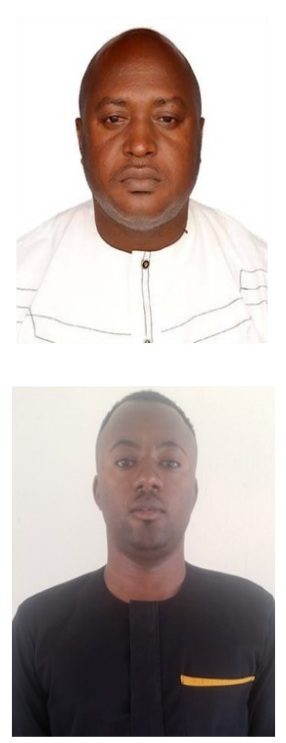

Joseph Mom earned his B. Eng in Electrical and Electronics Engineering from Joseph Sarwuan Tarka University in Makurdi, Nigeria, in 2004, and his M. Eng and Ph.D. in Electronics Engineering from the University of Nigeria Nsukka in 2009 and 2015, respectively. He is currently an associate professor at Joseph Sarwuan Tarka University in the Department of Electrical and Electronics Engineering. He has a long list of publications in prestigious journals and conference proceedings. He is a member of the IEEE and the ACM, as well as a registered engineer with the Council for the Regulation of Engineering in Nigeria (COREN).

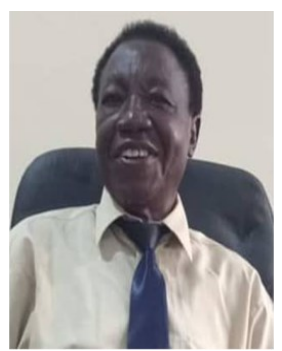

Gabriel Igwue holds a B.Sc from the University of Lagos in 1973; M.Sc from the Massachusetts Institute of Technology, USA and a Ph.D from the North Caroline State University, USA, all in Electrical Engineering in 1975 and 1982 respectively. Professor Igwue has taught Electrical Engineering courses at both polytechnic and University for over thirty years. He has held many management positions in the public and private sectors. He is a registered member of NSE and COREN. He has written several books in Electrical Engineering including Circuit Theory; Electrical Engineering Materials; Mathematical Methods for Engineers; Principles of Communications and Basic Circuit Theory and Industrial Electronics for physicists. He is married with children. 